\title{
The Growth of Hard Coral (Acropora sp.) Transplants in Coral Reef of Malalayang Waters, North Sulawesi, Indonesia
}

\author{
Alex Denny Kambey ${ }^{1}$ \\ ABSTRACT
}

Main coral reef building components, Scleractinian corals, has the highest distribution in Indonesia, at least 590 species known of 793 species in the world. Studies on damaged coral community transplantation have been done to observe their growth and adaptation ability.

A four-month observation found that average length increment at $9 \mathrm{M}$ deep was linearly $0.375 \mathrm{~cm}, 0.632 \mathrm{~cm}$, and $0.732 \mathrm{~cm}$ at the first, second, and third month, respectively, at $6 \mathrm{M}$ deep, it was $0.455 \mathrm{~cm}, 0.689 \mathrm{~cm}$, and $1.012 \mathrm{~cm}$, at the first, second and third month, respectively, and at $3 \mathrm{M}$ deep, it was $0.55 \mathrm{~cm}, 1.05 \mathrm{~cm}$ and 1.1 , at the first, second, and thrid month, respectively. Mean relative length increment at $9 \mathrm{M}$ deep occurred every month as much as $4.25 \%, 8.23 \%$, and $9.86 \%$ at the first, second, and third month, respectively. Similarly, it occurred in $6 \mathrm{M}$ deep, $4.12 \%, 9.14 \%$, and $11.28 \%$ at the first, second, and third month, respectively. However, at $3 \mathrm{M}$ deep, it occurred only at the first and second month, $7.33 \%$ and $12.73 \%$, while it declined at the third month, $11.7 \%$.

Keywords : Ecosystems, Coral Reef, Scleractinia, Malalayang, Manado

\section{ABSTRACT}

Komponen utama penyusun terumbu yakni coral (Scleractinia) memiliki distribusi tertinggi di Indonesia, sekurang-kurangnya diketahui 590 spesies dari 793 jenis yang ada di dunia. Penelitian tentang transplantasi pada suatu komunitas yang telah rusak dilakukan untuk melihat pertumbuhan dan kemampuan beradaptasi.

Penelitian selama empat bulan pengamatan, rata-rata pertambahan panjang secara linier pada kedalaman 9 meter; bulan pertama $0,375 \mathrm{~cm}$, bulan kedua $0,632 \mathrm{~cm}$, dan bulan ketiga $0,732 \mathrm{~cm}$. Pada kedalaman 6 meter; bulan pertama sebesar $0,455 \mathrm{~cm}$, bulan kedua $0,689 \mathrm{~cm}$, dan bulan ke tiga $1,012 \mathrm{~cm}$, sedangkan di kedalaman 3 meter; bulan pertama sebesar $0,55 \mathrm{~cm}$, bulan kedua $1,05 \mathrm{~cm}$ dan bulan ketiga 1,1 . Persentase rata-rata pertambahan panjang relatif di kedalaman $9 \mathrm{~m}$ mengalami peningkatan setiap bulannya. Bulan pertama 4,25 persen, bulan kedua 8,23 persen, dan bulan ketiga 9, 86 persen. Begitu juga di kedalaman 6m bulan pertama 4,12 persen, bulan kedua 9,14 persen, dan bulan ketiga 11,28 persen. Di kedalaman $3 \mathrm{~m}$ hanya bulan pertama dan bulan kedua mengalami peningkatan yaitu bulan pertama sebesar 7,33 persen, bulan kedua 12,73 persen sedangkan dari bulan kedua sampai bulan ketiga mengalami penurunan sebesar 11,7 persen.

Keywords : Ekosistim, Terumbu Karang, Scleractinia, Malalayang, Manado

\section{'Staf pengajar Fakultas Perikanan dan IImu Kelautan Universitas Sam Ratulangi}

\section{PENDAHULUAN}

Terumbu karang merupakan ekosistem perairan laut dangkal yang sangat produktif, ekosistem ini sangat beragam taksonominya yang bertempat pada pelataran kalsium karbonat $(\mathrm{CaCO} 3)$ yang keras (tapi berpori), terbentuk selama selama periode yang panjang melalui pertumbuhan yang bergantian pengendapan dan konsolidasi sisa-sisa cangkang terutama karang (ordo Scleractinia) hermatipik (pembentuk terumbu) serta kalsifikasi sisa-sisa 
cangkang moluska dan alga berkapur. Ekosistem ini memiliki fungsi alamiah sebagai lingkungan hidup, pelindung fisik bagi pulau dan daratan, sumberdaya hayati dan sumber keindahan. Sebagai lingkungan hidup dan tempat hidup, terumbu karang menjadi tempat organisme berkembang biak dan berproduksi.

Terumbu karang dan segala kehidupan yang ada di dalamnya merupakan salah satu kekayaan alam yang dimiliki bangsa Indonesia yang tak ternilai harganya. Kepulauan Indonesia memiliki keanekaragaman hayati yang tinggi di dunia, disebut sebagai 'center of biodiversity', dan merupakan 'key of marine area' atau 'the heart of coral triangle'. Namun di balik kebanggaan potensi, nilai dan manfaat ekosistem terumbu karang yang strategis; kuantitas (luasan) dan kualitasnya dari tahun ke tahun merosot tajam (TNC 2004, Wilkinson 2004, Tun et al 2008).

Berbagai permasalahan global mengancam ekosistem laut dunia termasuk Indonesia yang pada akhirnya menyebabkan kehancuran ekosistem terumbu karang. Pola pembangunan wilayah pesisir dan lautan selain telah menghasilkan sejumlah keberhasilan juga telah meningkatkan kerusakan terumbu karang di hampir seluruh perairan Indonesia, berbagai kegiatan pemanfaatan wilayah pesisir seperti pertanian, industri, pengerukan pantai, penangkapan ikan dengan racun serta bom ikan, reklamasi pantai dan peristiwa alami seperti gempa bumi, sedimentasi, El Nino dan Tsunami dapat menganggu atau merusak terumbu karang. Sejalan dengan meningkatnya penduduk dan kesejahteraan masyarakat memacu manusia untuk mengeksploitasi sumberdaya secara besar-besaran tanpa memperhitungkan akibatnya. Kebutuhan ekonomi yang tinggi mendorong manusia melakukan pola destruktif dalam memanfaatkan sumberdaya alam dengan hanya memikirkan keuntungan jangka pendek dan keuntungan diri sendiri tanpa memikirkan akibat yang ditimbulkan bagi masyarakat umum di waktu mendatang.

Terumbu karang di semenanjung Sulawesi Utara tak luput dari permasalahan yang sama. Hewan pemakan coral ganas Acanthaster planci (pumparade) yang semakin meningkat, masuknya sampah/eutrofikasi, tekanan akibat aktivitas manusia yang berlebihan, memang akibat dari kombinasi tersebut tidak dapat diprediksi dampak kerusakan ataupun kepunahaan karang cepat ataupun lambat, namun antisipasi dan upaya penyelamatan sangatlah diperlukan. Perairan pantai Malalayang yang terdapat di wilayah perairan Teluk Manado memiliki terumbu karang yang potensial dikembangkan. Namun sangat disayangkan terumbu karang yang terdapat di sekitar perairan tersebut terancam akibat aktivitas manusia seperti reklamasi dan kegiatan wisata pantai. Beberapa areal dari terumbu di wilayah tersebut telah mengalami kerusakan baik secara alamiah maupun diakibatkan oleh manusia seperti penangkapan ikan dengan alat tangkap yang tidak ramah lingkungan, ancaman degradasi keanekaragaman hayati ekosistem terumbu karang ini tentunya memerlukan perhatian guna kelestarian sumberdaya yang ada. Langkah konservasi seperti penetapan daerah perlindungan laut maupun restorasi/rehabilitasi ekosistem saat ini menjadi tantangan tersendiri dalam upaya pelestarian sumberdaya. Rehabilitasi dan restorasi biologis pada ekosistem terumbu karang berupa transplantasi hewan karang secara langsung dapat meningkatkan dan memulihkan terumbu yang terdegradasi.

Kerusakan ekosistem terumbu karang yang terjadi saat ini telah memperparah kuantitas dan kualitas hewan karang sebagai komponen utama pembentuk terumbu. Isu pemanasan global adalah peringatan 
tentang perubahan yang menglobal, peningkatan suhu air laut dan pengasaman laut (ocean acidification) menambah kritisnya kondisi ekosistem yang penting ini. Secara aktual, over/destructive-fishing, pembangunan dan tekanan yang meningkat di wilayah pesisir diikuti polusi dan sedimentasi serta perubahan iklim (climate change) berkontribusi terhadap berkurangnya terumbu dunia termasuk di semenanjung Sulawesi Utara, Indonesia. Ekosistem terumbu karang di pantai Malalayang telah lama dikenal memiliki sumberdaya laut yang sangat potensial, namun turut terancam akibat aktivitas yang diakibatkan manusia langsung maupun tidak langsung. Ekosistem yang langsung bersinggungan dengan wilayah wisata pantai masyarakat ini terancam dengan pencemaran, banyaknya sampah, sedimentasi dan beberapa eksploitasi pemanfaatan sumberdaya yang tidak ramah lingkungan termasuk reklamasi pembangunan pantai.

Selain permasalahan tersebut di atas, di sisi lain teknologi konservasi untuk memulihkan dan meningkatkan kuantitas dan kualitas hewan karang masih kurang diterapkan. Penerapan teknik transplantasi langsung ke terumbu yang relatif kurang menarik terutama pada terumbu yang kosong atau berupa substrat skeleton hewan karang yang mati masih kurang dilakukan. Beberapa langkah konservasi yang dilakukan dewasa ini masih terbatas pada transplantasi dan pembibitan hewan karang dalam wadah tertentu yang umumnya mahal dilakukan. Dengan memperhitungkan jenis karang dan dilakukan dengan hatihati tentunya akan turut meningkatkan keanekaragaman dan kekayaan jenis karang, secara tidak langsung akan meningkatkan nilai dari suatu ekosistem.

Penyebab terjadinya kerusakan
terumbu karang pada umumnya
disebabkan oleh ulah manusia
terumbu karang pada umumnya disebabkan oleh ulah manusia langsung maupun tidak langsung seperti yang telah dijelaskan mendetail sebelumnya. Langkah konservasi seperti penetapan daerah perlindungan laut maupun restorasi/rehabilitasi ekosistem saat ini menjadi tantangan tersendiri dalam upaya pelestarian sumberdaya. Rehabilitasi dan restorasi biologis pada ekosistem terumbu karang berupa transplantasi hewan karang secara langsung dapat meningkatkan dan memulihkan ekosistem terumbu yang terdegradasi.

Dalam memulihkan kondisi
terumbu karang secara alami dibutuhkan waktu yang sangat lama. Namun saat ini telah dikenal banyak metode, salah satunya adalah metode transplantasi karang. Transplantasi karang merupakan salah satu upaya rehabilitasi terumbu karang melalui pencangkokan atau pemotongan karang hidup yang selanjutnya ditanam di tempat lain yang mengalami kerusakan atau menciptakan habitat yang baru pada lahan yang kosong. Manfaat dari transplantasi karang adalah mempercepat regenerasi terumbu karang yang telah rusak, rehabilitasi lahan-lahan kosong atau yang rusak sehingga dapat mendukung ketersediaan jumlah populasi ikan karang di alam, menciptakan komunitas baru, pengembangan populasi karang yang memiliki nilai ekonomis tinggi dan keperluan perdagangan (Edwards dan Clarck 1988, Kaleka 2004).

Restorasi biologis harus selalu dipertimbangkan terutama dalam hal pengembalian kondisi lingkungan secara keseluruhan baik aspek fisik, biotik, manusia hingga pengelolaan. Restorasi ekologis adalah proses membantu pemulihan alami sebuah ekosistem yang kondisinya telah menurun, rusak, atau hancur. Bantuan tersebut dapat dilakukan secara tidak langsung dengan pengelolaan terumbu karang sehingga dapat menghilangkan hal-hal yang menghalangi pemulihan alami, atau secara langsung dengan melakukan restorasi biologis secara 
aktif seperti transplantasi karang atau biota lainnya. Contoh untuk yang pertama dapat berupa pengelolaan untuk mengurangi tekanan akibat perikanan, limpasan sedimen, atau masuknya limbah. Dengan demikian restorasi biologis secara pasif dapat dilakukan melalui berbagai kegiatan pengelolaan pesisir yang dapat mengurangi tekanan antropogenik terhadap ekosistem terumbu karang (Pickering et al 1999, Bowden-Kerby 2008).

Kegiatan restorasi biologis
secara aktif yang paling sering
dilakukan adalah transplantasi karang
atau biota lain pada kawasan yang
sudah rusak. Yang harus diingat adalah
minimalisasi kerusakan terhadap
kawasan yang lebih baik yang menjadi
donor transplantasi, dan memaksimalkan kemungkinan hidup transplan pada terumbu yang akan dipulihkan Akhirnya kegiatan restorasi hanya dapat berhasil dalam jangka panjang jika komunitas di terumbu karang telah mandiri dan berfungsi dengan baik (Bowden-Kerby 2008, Edwards \& Gomez 2008). Saat ini sudah tersedia banyak pilihan yang menjanjikan hasil yang baik sehingga para praktisi dapat mengurangi efek samping mulai dari pemilihan sumber transplantasi hingga memaksimalkan efektivitas dari karang yang digunakan. Pilihan yang tersedia mulai dari bagaimana memilih sumber transplantasi, baik dengan propagasi seksual maupun aseksual secara in situ (di laut) atau ex situ (di akuarium)

\section{METODE}

Sebelum kegiatan transplantasi dimulai, survey awal dengan menggunakan SCUBA (self containe breathing apparatus) dilakukan untuk mengidentifikasi jenis karang induk dan lokasi terumbu yang cocok untuk penelitian ini (Hill dan Wilkinson 2004). Induk karang yang yang akan dijadikan bibit transplantasi adalah jenis karang batu bercabang dan sehat dari genus
Acropora sp. (Veron 2000) yang terdapat di daerah tersebut. Lokasi transplantasi yang akan dipilih adalah pada terumbu terdegradasi atau pada terumbu dengan tutupan dan keragaman jenisnya relatif rendah. Bibit atau fragmen karang ditransplantasi pada substrat keras kapur (calcium carbonat) yang merupakan material sisa (skeleton) dari karang yang telah mati, ditentukan pada 3 kedalaman berbeda masingmasing di 3, 6, dan 9 meter.

Pengambilan bibit / fragmen dari induk karang Acropora dilakukan secara hati-hati menggunakan penjepit (tang) untuk memotong ujung cabang dengan kisaran panjang antara 6-10 $\mathrm{cm}$. Fragmen yang telah dipotong dikumpulkan ke dalam keranjang dan dibawa pada lokasi transplantasi masing-masing sebanyak 30 fragmen per kedalaman $(3,6$, dan 9 meter). Teknik transplantasi fragmen ke substrat karang mati adalah mencari lubang alami berdiameter yang sama dengan fragmen, atau melubangi terumbu dengan bor, pahat ataupun obeng sesuai ukuran. Area di sekitar lubang transplantasi dikikis hingga bersih kemudian fragmen di masukkan dan distabilkan dengan perekat epoxy di satu sisi dan di sisi lainnya ditekan hati-hati hingga menyentuh substrat, proses ini akan mempercepat penempelan fragment pada substrat. Jarak terdekat antara fragmen satu dengan yang lainnya kurang lebih 20 centimeter.

Pengukuran panjang dilakukan setelah semua fragmen (90 fragmen) selesai ditransplantasi (data awal). Fragmen akan diukur mulai dari pangkal yang dibatasi dengan garis epoxy sampai pada ujung cabang dengan ketelitian $1 \mathrm{~mm}$. Pengamatan perkembangan fragment yaitu ketahanan hidup dan pertumbuhannya akan dilakukan setiap bulannya selama 3 bulan (akhir pengambilan data). Pencatatan data bawah air dengan menggunakan underwater sheet dan di 
dokumentasikan dengan kamera bawah air.

\section{HASIL DAN PEMBAHASAN Pertambahan Panjang Berdasarkan Panjang Linier}

Hasil pengukuran pertambahan panjang transplan karang Acropora $s p$ menunjukan adanya peningkatan selama empat bulan, yaitu dari bulan agustus-november 2010. Grafik di bawah ini menggambarkan pertambahan panjang secara linier pada tiga kedalaman berbeda yaitu kedalaman 9m, 6m, dan $3 \mathrm{~m}$. Pertambahan panjang secara linier pada masing-masing kedalaman menunjukan adannya peningkatan dari awal sampai akhir pengukuran dan diperkirakan masih akan terus bertambah panjang.

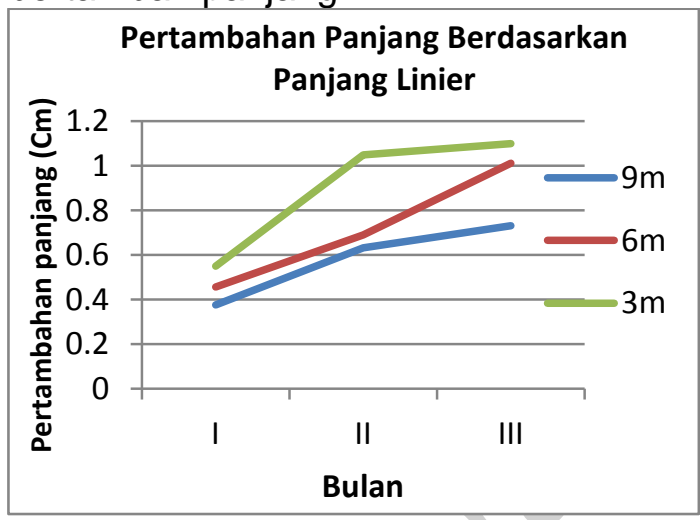

Gambar 1. Pertambahan panjang berdasarkan panjang linier

Rata-rata pertambahan panjang secara linier selama empat bulan pada kedalaman 9 meter yaitu bulan pertama $0,375 \mathrm{~cm}$ bulan kedua 0,632 cm sedangkan bulan ketiga $0,732 \mathrm{~cm}$, pada kedalaman 6 meter rata-rata pertambahan panjang bulan pertama yaitu sebesar $0,455 \mathrm{~cm}$ bulan kedua $0,689 \mathrm{~cm}$ bulan ke tiga $1,012 \mathrm{~cm}$, sedangkan di kedalaman 3 meter ratarata pertambahan panjang linier bulan pertama yaitu sebesar $0,55 \mathrm{~cm}$, bulan kedua 1,05 cm dan bulan ketiga 1,1.

Untuk mengetahui apakah terjadi perbedaan pertambahan panjang cabang di tiga kedalaman berbeda selama empat bulan dilakukan uji statistik yaitu dengan menggunakan anova
Hasil pengamatan terlihat jelas bahwa hasil pengukuran selama empat bulan dengan menggunakan uji statistik anova tidak berbeda nyata karena dilihat dari tabel di atas selama empat bulan pengukuran f-hitung lebih kecil dari f-tabel dimana pada bulan pertama f-hitung $(1,745193)<$ f-tabel $(3,21448)$, bulan kedua f-hitung $(0,506143)<\mathrm{f}$ tabel $(3,21448)$ juga bulan ketiga $f-$ hitung $(0,813683)<$ f-tabel $(3,38519)$.

Laju rata-rata pertambahan panjang secara linier di kedalaman 9 meter, 6 meter, dan 3 meter selama empat bulan yaitu dari bulan agustusnovember meningkat dari bulan pertama atau awal pengambilan data dimana nilai tertingi pada akhir bulan kondisi ini belum mencapai pertambahan panjang karang pada umumnya dimana kurva pertambahan panjang tersebut secara logistik biasannya mencapai batas tertinggi atau nilai maksimum pertabahan panjang yang stabil dihubungkan dengan waktu, pertambahan panjang karang di tiga kedalaman berbeda ini terjadi dalam waktu singkat dengan nilai rata-rata selama empat bulan pada kedalaman 9 meter berkisar antara 0,37-0,73 cm, kedalaman 6 meter berkisar antara 0,63-1,01 cm begitu juga di kedalaman 3 meter berkisar antara 0,55-1,1 cm, sedangkan untuk mencapai stabilitas pertambahan panjang karang maka penelitian membutuhkan waktu yang cukup lama kurang lebih satu tahun penelitian sehingga dapat diketahui periode maksimum dimana pertambahan panjang transplant karang tersebut dapat menjadi stabil.

Persentase

rata-rata pertambahan panjang relatif pada kedalaman 9, 6 dan 3 meter selama empat bulan juga mengalami peningkatan hanya saja pada kedalaman $3 \mathrm{~m}$ pada bulan terakhir mengalami penurunan. Perbedaan pertumbuhan di masing-masing kedalaman berbeda ini berhubungan dengan kemampuannya memperoleh cahaya untuk dapat bertumbuh. Laju 
pertumbuhan karang dipengaruhi oleh sifatnya yang fototorik sehingga dalam bertumbuh karang jenis Acropora cenderung mendapatkan cahaya yang lebih banyak, hal ini juga berhubungan dengan laju kalsifikasi karang dimana pertumbuhan kearah atas maka semakin besar intensitas cahaya yang masuk. Zooxanthellae dalam jaringan karang meningkatkan kemampuan untuk melakukan fotosintesis sehingga kalsifikasi struktur untuk perkembangan semakin cepat.

\section{Pertambahan Panjang Relatif}

Pertambahan panjang Relatif karang acroopora sp selama 3 bulan pada masing-masing kedalaman mengalami peningkatan setiap bulannya dapat dilihat dari grafik di bawah pada kedalaman $9 \mathrm{~m}$ dari bulan petama sampai bulan ketiga dapat mengalami peningkatan begitu juga di kedalaman $6 \mathrm{~m}$ dari bulan pertama sampai bulan ketiga juga mengalami peningkatan hanya saja di kedalaman $3 \mathrm{~m}$ bulan kedua mengalami peningkatan tetapi bulan ketiga mengalami penurunan.

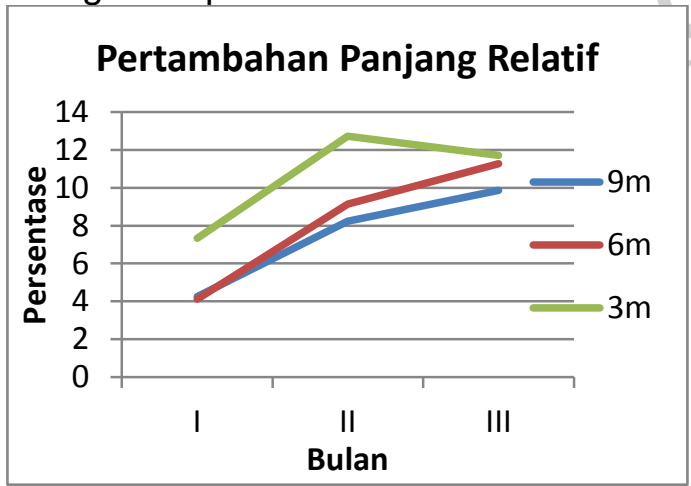

Gambar 2. Pertambahan panjang relatif

Persentase

rata-rata

pertambahan panjang relative di kedalaman $9 \mathrm{~m}$ mengalami peningkatan setiap bulannya bulan pertama 4,25 persen, bulan kedua 8,23 persen, bulan ketiga 9, 86 persen begitu juga di kedalaman $6 \mathrm{~m}$ bulan pertama 4,12 persen, bulan kedua 9,14 persen bulan ketiga 11,28 persen tetapi beda halnya di kedalaman $3 \mathrm{~m}$ hanya bulan pertama mengalami peningkatan yaitu bulan pertama 7,33 persen, bulan kedua
12,73 persen sedangkan dari bulan kedua sampai bulan ketiga mengalami penurunan sebesar 11,7 persen.

\section{Kemampuan Karang Beradaptasi}

Hasil pengamatan selama tiga bulan setelah karang ditransplantasi ke stasiun penelitian terlihat bahwa sebagian karang yang mengeluarkan lendir (Mocus) pada awal penelitian teetapi di hari berikunya lendir tersebut dapat hilang

Hal ini dikarenakan pada saat fragmen karang dipatahkan dari induknya dsn ditempatkan pada suatu wadah tertentu karang tersebut mengalami stres. Sama halnya dengan penelitian yang dilakukan Sadarun (1999) menyatakan bahwa karang jenis Acropora formosa kembali normal dari mngalami stress dalam waktu yang singkat pada kisaran penyembuhan 513 hari. Awal pertumbuhan karang ditandai dengan mulai menutupnya bekas potongan yang terjadi pada saat fragmentasi, kecepatan sembuh karang sangat berkaitan dengan proses klasifikasi karang tersebut sedangkan laju klasifikasi karang sangat bergantung pada jenis dan keberadaan karang tersebut.

\section{KESIMPULAN}

Pertambahan rata-rata panjang cabang secara linier pada masingmasing kedalaman yang sama yaitu 9 meter pada bulan pertama sampai yang keempat mengalami penigkatan. Sama halnya di kedalaman 6 dan 3 meter juga mengalami peningkatan pertambahan panjang setiap bulannya.

Hasil analisis anova tidak terlihat perbedaan nyata antara 3 kedalaman selama empat bulan pengamatan

\section{DAFTAR PUSTAKA}

Bowden-Kerby A (2008) Coral Transplantation and Restocking to Accelerate the Recovery of Coral Reef Habitats and Fisheries Resources Within No- 
Take Marine Protected Areas: Hands-On Approaches to Support Community-Based Coral Reef Management. Intern. Tropical Marine Ecosystem Management Symposium, Manila Phillipines. 15p.

Edwards AJ and S Clarck (1988) Coral Transplantation: A Useful Management Tool or Misguided Meddling? Marine Pollution Bulletin Vol. 37, Nos. 8-12, pp. 474-487.

Edwards AJ and ED Gomez (2008) Reef Restoration Concepts and Guidelines: Making Sensible Management Choices in the Face of Uncertainty. Diterj.oleh: Yusri, S., Estradivari, N. S. Wijoyo, \& Idris. Yayasan TERANGI, Jakarta: 38 hal.

Hill $\mathrm{J}$ and C Wilkinson (2004) Methods for Ecological Monitoring of Coral Reefs. A Resource for Manager ver.1. Reefbase, GCRMN, Reef Check. AIMS publ. ISBN 0642322376. 123p.

Kaleka DMW (2004) Transplantasi Karang Batu Marga Acropora Pada Substrat Buatan di Perairan Tablolong Kabupaten Kupang. Makalah Falsafah Sains (PPS 702), Program S3 IPB. 8 hal.

Lalamentik LTX dan UNWJ Rembet (1996) Penilaian Kondisi Terumbu Karang Dengan Penekanan Pada Karang Batu. Metodologi Penelitian Terumbu
Karang. P3O LIPI Sumberdya Alam Ambon dan Fakultas Perikanan UNSRAT Manado. 42 hal.

Pickering $H$, D Whitmarsh, A Jensen (1999) Artificial Reefs as a Tool to Aid Rehabilitation of Coastal Ecosystems: Investigating the Potential. Marine Pollution Bulletin Vol. 37, Nos. 8-12, pp 505-514

Sadarun.1999. Tranplantasi karang batu (Stony Coral) di kepulauan seribu teluk Jakarta. Thesis. Institute Pertanian Bogor. 67 hal.

The Nature Conservancy (2004) Delineating the Coral Triangle, its ecoregions and functional seascapes. Report from The Nature Conservancy, Southeast Asia Centre for Marine Protected Area. Compiled by Dr. A Green and PJ Mous. 26p.

Tun K, CL Ming, $T$ Yeemin, N Phongsuwan, AY Amri, N Ho, $\mathrm{K}$ Sour, NV Long, C Nanola, D Lane, Y Tuti (2008) Status of Coral Reefs in Southeast Asia; in the Status of Coral Reefs of the World 2008 (131-144)

Veron JEN (2000) Corals of the World. Australian Institute of Marine Science, Vol.1-3.

Wilkinson C (2004) Status of Coral Reefs of the World. Global Coral Reef Monitoring Network. AIMS. Vol. 1, 301p 
Lampiran :
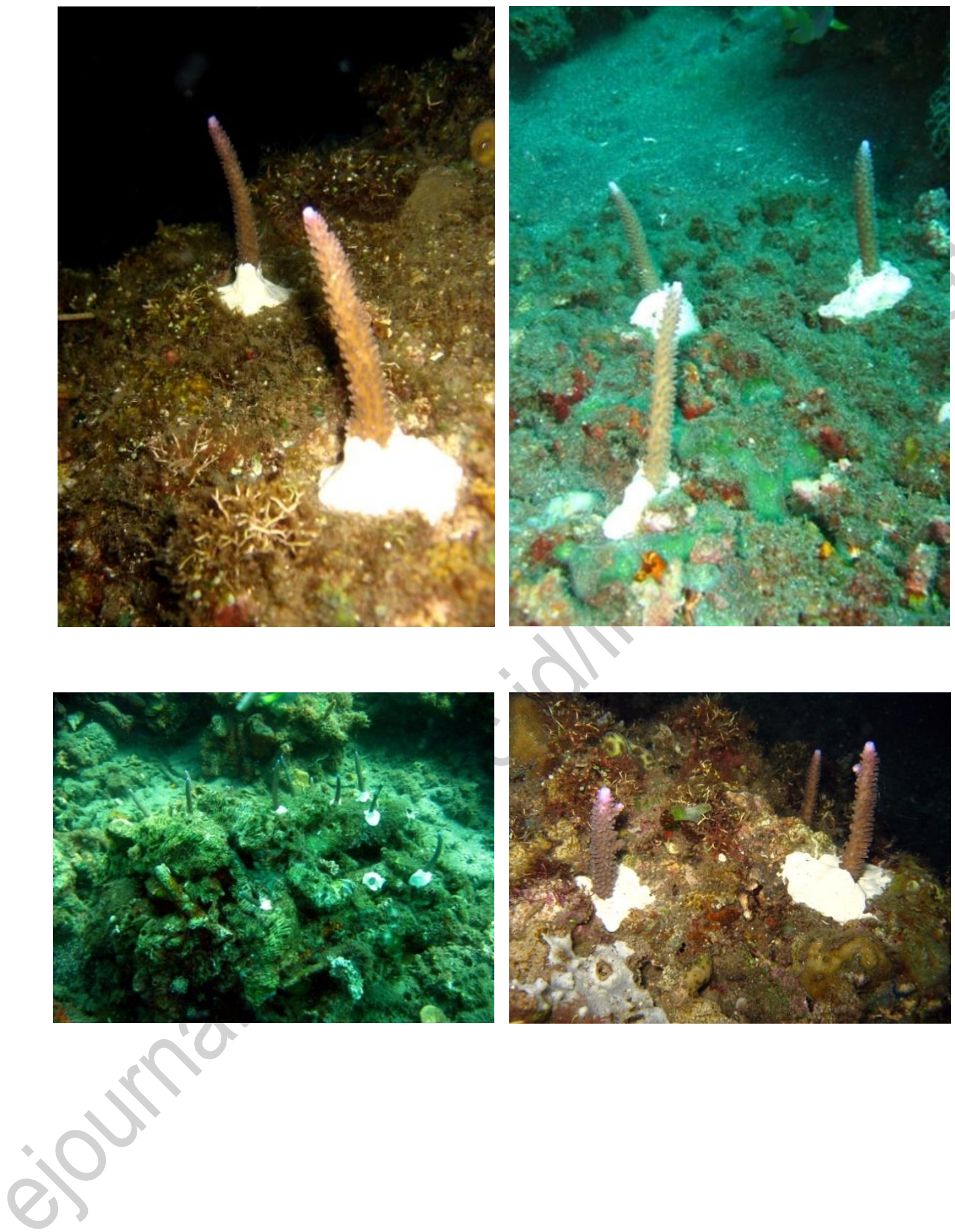